\title{
Primary diffuse tracheo-bronchial amyloidosis
}

\author{
MARIA L. ANTUNES AND J.M. VIEIRA DA LUZ \\ From the Department of Chest Diseases, University of Lisbon Medical School, Portugal
}

A case of diffuse tracheo-bronchial amyloidosis in a 62-year-old woman thought to have chronic bronchitis is reported. The immunological mechanism in the pathogenesis of this condition is considered and the need for bronchological investigation in chronic bronchial disorders is stressed.

\section{CASE REPORT}

A. V. A., a 62-year-old housewife, born in Faro (in the Portuguese southern province of Algarve), had had an episode of haemoptyses at the age of 27 ; she was admitted to hospital, where mitral stenosis was diagnosed. There were no other symptoms at the time. The haemoptysis recurred at 40 and 43, again without other complaints. At 56 she had a respiratory illness with dyspnoea, cough, purulent sputum, and fever $\left(38.5^{\circ} \mathrm{C}\right.$.). Antibiotics were administered and the patient recovered. Since then asthma-like episodes have occurred, with wheezing, not related to exertion but to cold and wet weather. She was worse in winter and was frequently hospitalized for treatment.

Two years ago blood-stained sputum appeared during the acute attacks. Physical examination showed a thin, elderly woman with a pulse rate of $110 /$ minute. Scattered wheezes were heard over both lung fields, but no signs of upper respiratory stenosis were present. The first heart sound at the apex was sharp and loud and, on exercise only, a diastolic murmur grade 1 or 2 in 4 was heard. Rhythm was normal. Sputum cultures were nega-
FIG. 1. Chest radiograph showing mild generalized emphysema.

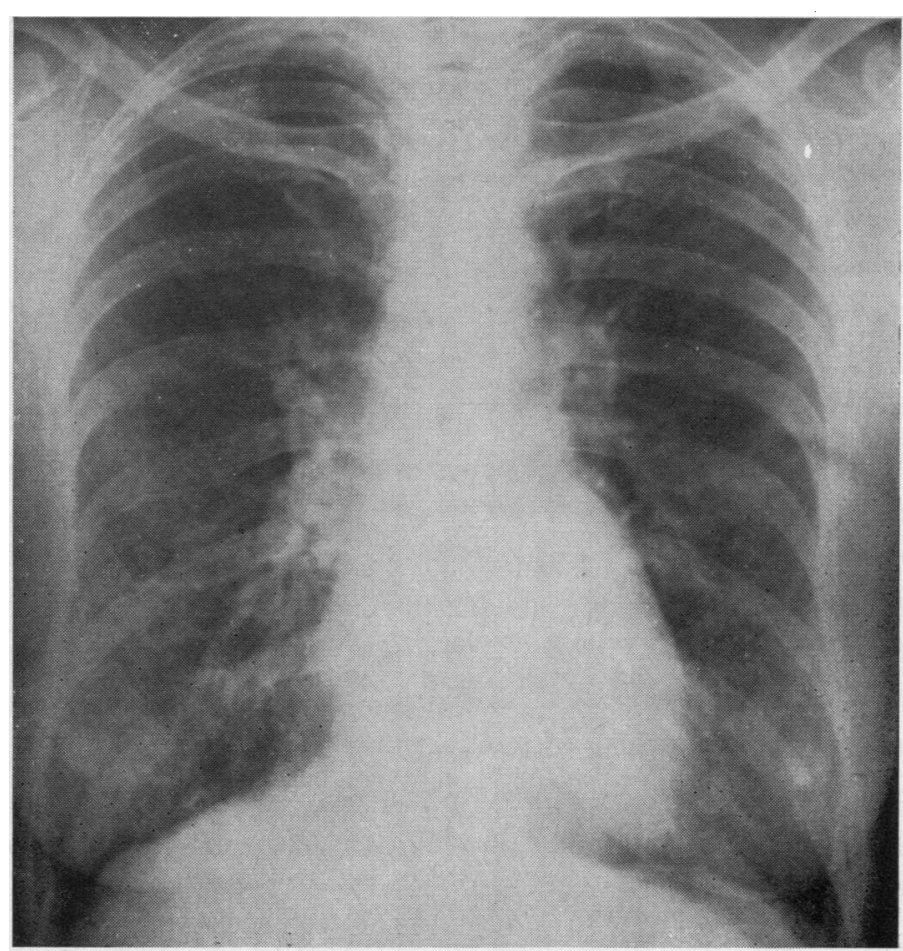


tive. E.S.R. was $34 \mathrm{~mm}$./hour. Urinalysis, blood count and differential count, haemoglobin, blood sugar, and nonprotein nitrogen were within normal limits. An electrocardiogram showed a pattern of incomplete right bundle-branch block. The radiograph showed a slightly emphysematous chest with a vertical heart (Fig. 1).

Cytology of the sputum was negative. Lung function tests were performed by the methods in routine use at the department's Pulmonary Function Laboratory and the results are shown in Table I. They indicated a mixed type of respira-

T A B L E I

PULMONARY FUNCTION STUDIES

\begin{tabular}{|c|c|c|c|c|c|}
\hline & & & & Observed & Predicted \\
\hline \multicolumn{4}{|c|}{ 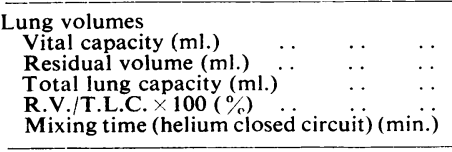 } & $\begin{array}{r}1,500 \\
3,700 \\
5,200 \\
71 \\
5\end{array}$ & $\begin{array}{l}2,800 \\
1,100 \\
3,700\end{array}$ \\
\hline \multicolumn{4}{|c|}{$\begin{array}{lll}\text { Ventilation } & & \\
\text { Frequency (respirations/min.) } & \ldots & \ldots \\
\text { Tidal volume (ml.) } & \ldots & \ldots \\
\text { Minute-volume (ml./min.) } & \ldots & \ldots \\
\begin{array}{l}\text { Alveolar ventilation (ml./min.) } \\
\text { Physiological dead space (ml.) }\end{array} & \ldots & \ldots \\
\begin{array}{l}\text { Physiological dead space ventilation (mi./ } \\
\text { min }\end{array}\end{array}$} & $\begin{array}{r}18 \\
260 \\
4,700 \\
3,800 \\
45\end{array}$ & $\begin{array}{r}15 \\
340 \\
5,100 \\
3,200 \\
125\end{array}$ \\
\hline \multicolumn{4}{|c|}{$\begin{array}{l}\text { Gas exchange } \\
\begin{array}{l}\text { Oxygen consumption }(\mathrm{ml} . / \mathrm{min} .) \\
\text { Respiratory exchange ratio }\end{array} \\
\end{array}$} & $\begin{array}{r}160 \\
0 \cdot 70\end{array}$ & $\begin{array}{c}180 \\
0 \cdot 70^{-1} \cdot 1\end{array}$ \\
\hline \multicolumn{4}{|c|}{ 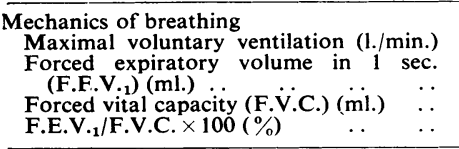 } & $\begin{array}{r}660 \\
1,500 \\
44\end{array}$ & $\begin{array}{r}2,800 \\
75-80\end{array}$ \\
\hline \multicolumn{2}{|l|}{$\begin{array}{l}\text { Blood gases } \\
\text { Oxygen saturation }(\%) \\
p \mathrm{H} .0 \text {. } \\
\text { Total CO } \\
\mathrm{CO}_{2} \text { tension (mm. } \% \\
\text { Bicarbonate (vol. } \%)\end{array}$} & $\begin{array}{l}\cdots \\
\cdots \\
\cdots \\
\cdots\end{array}$ & $\begin{array}{l}\cdots \\
\cdots \\
\cdots \\
\cdots\end{array}$ & $\begin{array}{l}92 \\
7 \cdot 54 \\
49 \cdot 7 \\
25 \cdot 8 \\
47 \cdot 9\end{array}$ & $\begin{array}{l}96 \\
7 \cdot 36-7 \cdot 42 \\
56-62 \\
36-42 \\
53-59\end{array}$ \\
\hline
\end{tabular}

tory insufficiency, both restrictive and obstructive, and a mild degree of emphysema. Alveolar hyperventilation with respiratory alkalosis and some arterial hypoxaemia were present. These findings were compatible with a clinical diagnosis of chronic bronchitis with considerable chest hyperinflation and possibly some degree of emphysema.

Bronchography performed routinely to study the tracheo-bronchial tree in chronic bronchitis showed, much to our surprise, a severe deformity of the trachea encroaching upon the lumen and occupying most of its length (Fig. 2). The walls of the main bronchi appeared to be thickened while the peripheral tree showed images of chronic bronchitis. Subsequently, at bronchoscopy, the larynx was found to be normal but the trachea was partially filled with numerous yellowish sessile tumours on both sides of the airway, covered by an intact mucosa (Fig. 3). The left main bronchus was infiltrated and its lumen quite reduced (Fig. $4 a)$. On the lateral wall of the right main bronchus

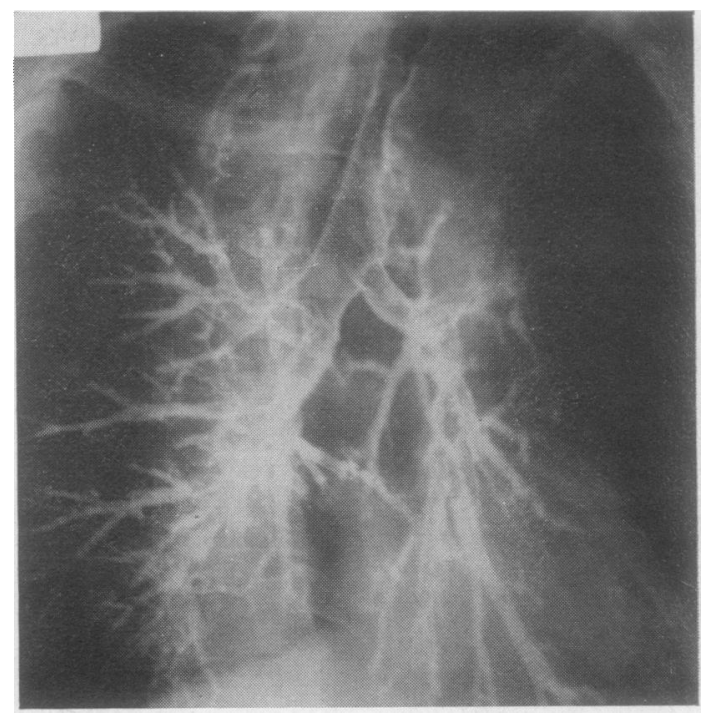

FIG. 2. Bronchography shows the deformity of the trachea and thickening of the large bronchi.

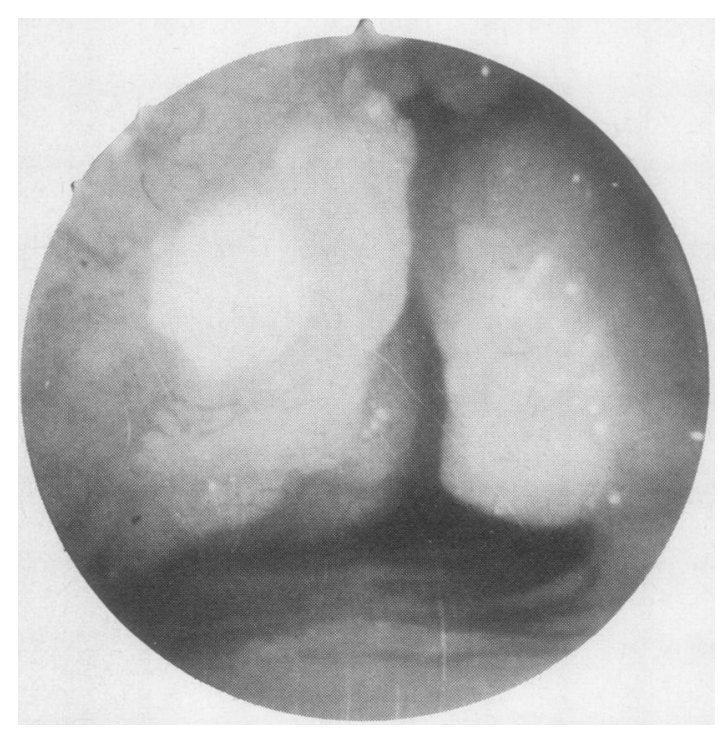

FIG. 3. Bronchoscopic view of the trachea. 


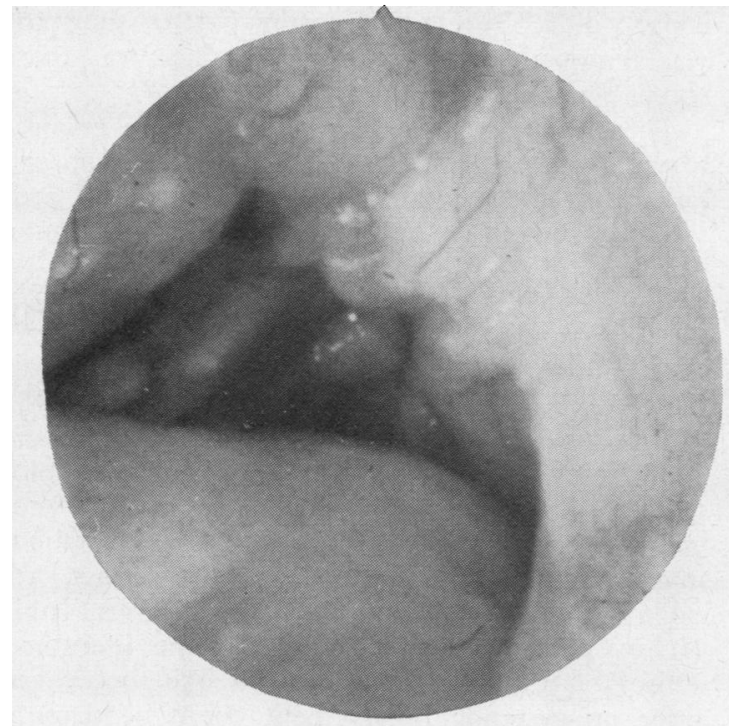

(a)

FIG. 4. Bronchoscopic view of the left (a) and right (b) main bronchi.

FIG. 5. Photomicrograph showing the amyloid deposit, the intact epithelium, and giant foreign-body cells (Congo Red).

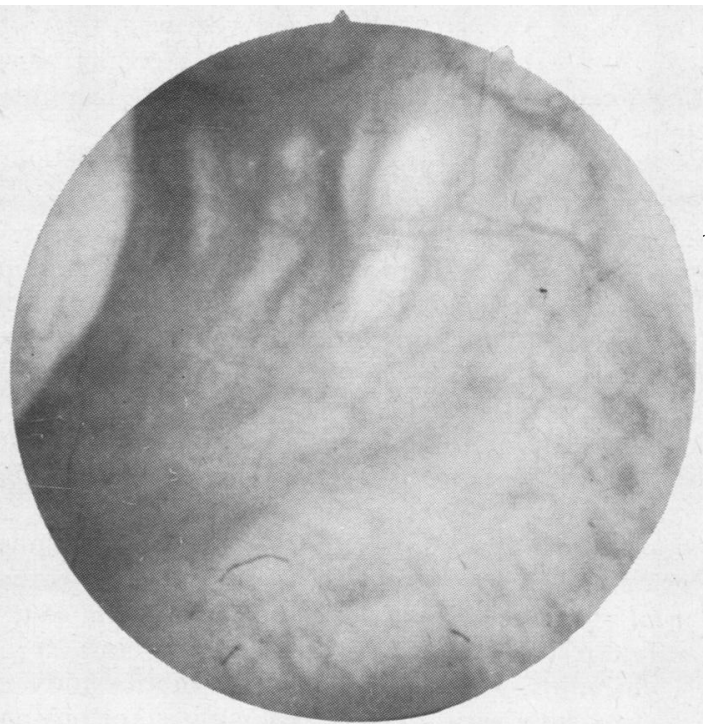

(b)

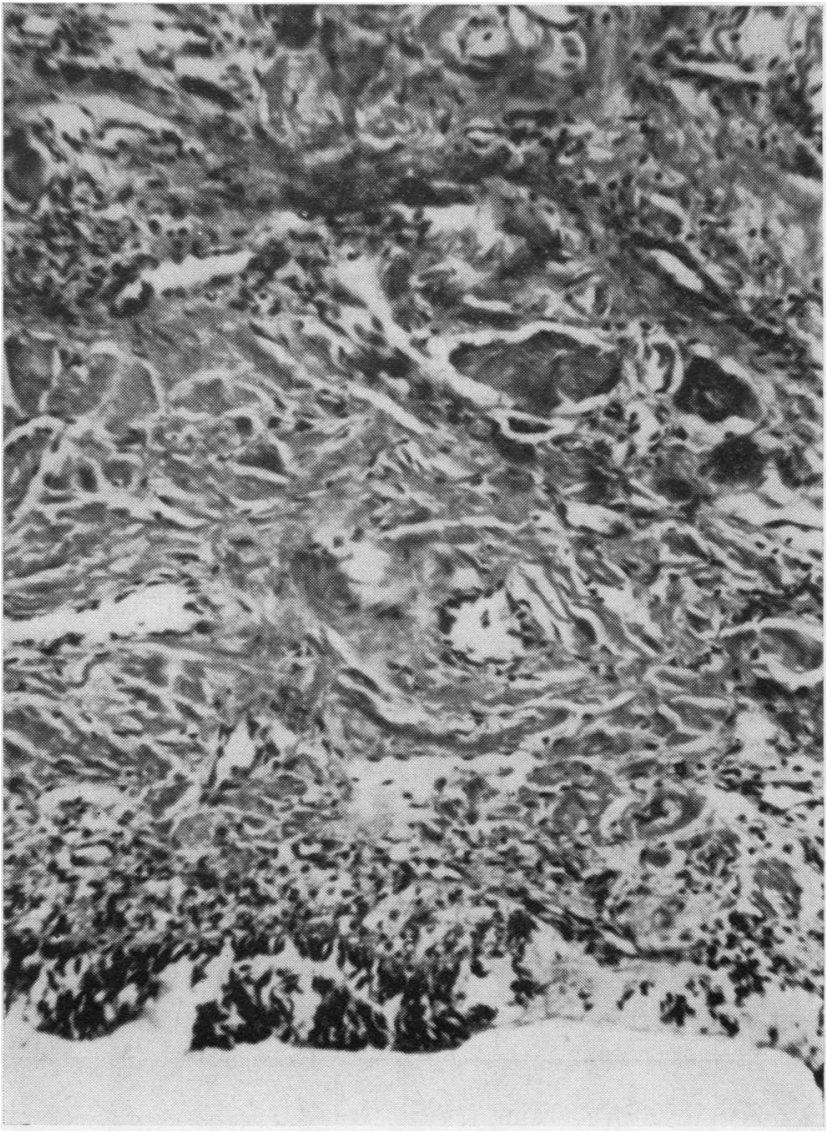


there were two small localized yellowish deposits (Fig. 4b). There was no significant bleeding when specimens were taken for pathological examination.

Microscopically there was an extensive deposit in the submucosa of a hyaline substance shown to be amyloid. The epithelium over the deposit was intact. No squamous metaplasia was demonstrated. Some giant foreign-body cells were present in relation to the amyloid and small calcifications were seen. There were no significant numbers of plasmocytes (Fig. 5).

The histological diagnosis of amyloid tumours of the trachea and bronchi was made and for this reason several investigations were undertaken. A barium swallow showed no change; Bence-Jones protein was not found in the urine. The serum total proteins were 7.40 g. $/ 100 \mathrm{ml}$, with $46.6 \%$ albumin, $6.1 \% \alpha_{1}, 13.6 \% \alpha_{2}, 13.2 \% \beta$, and $20.7 \%$ $\gamma$ globulins. An immunoelectrophoretic study of the patient's serum compared with a normal one disclosed an increase of $\beta_{2}$ and $\alpha_{2}$ M fractions and the line to IgA fraction had a double arch. These changes were not considered to be significant. Bone marrow aspiration biopsy disclosed no abnormality. The Congo Red test was in the upper limit of normal, the patient's blood retaining $75 \%$ of the amount of dye used one hour after the injection was performed.

Subsequently, three more bronchoscopies were performed at monthly intervals for removal of tissue. One of them was done three days after the intravenous injection of $10 \mathrm{ml}$. of $1 \%$ Congo Red dye and the deposits macroscopically were stained a dark pink. On every occasion part of the mass was removed with forceps. Only once was there some bleeding.

The patient was feeling well, no more respiratory infections occurred, and she was discharged and referred for follow-up observation and prospective bi-yearly removal of the remaining deposits.

\section{DISCUSSION}

Amyloidosis of the respiratory system was described as early as 1875 (Burow) and by 1935 95 cases were already known (Kramer and Som, 1935). However, cases with diffuse nodular infiltration of the trachea and bronchi causing progressive narrowing of the air passages, without involvement of the upper respiratory tract, are quite scarce and we could find only 18 cases (Table II), ours being the nineteenth in the literature. This is a primary, atypical form like the others, since no systemic involvement could be demonstrated. Also no connexion was found between this type of amyloidosis and the Portuguese familial form of the disease involving the nervous system, especially the peripheral nerves of the lower extremities (Da Silva Horta, Filipe, and Duarte, 1964).

Among the theories advocated for the pathogenesis of amyloidosis, some immunological mechanism with a local antigen-antibody reaction may be involved, and it is possible that in chronic bronchial disorders a continuous stimulation by a local source of antigen may lead to the deposition of amyloid (Prowse and Elliott, 1963).

T A B L E I I

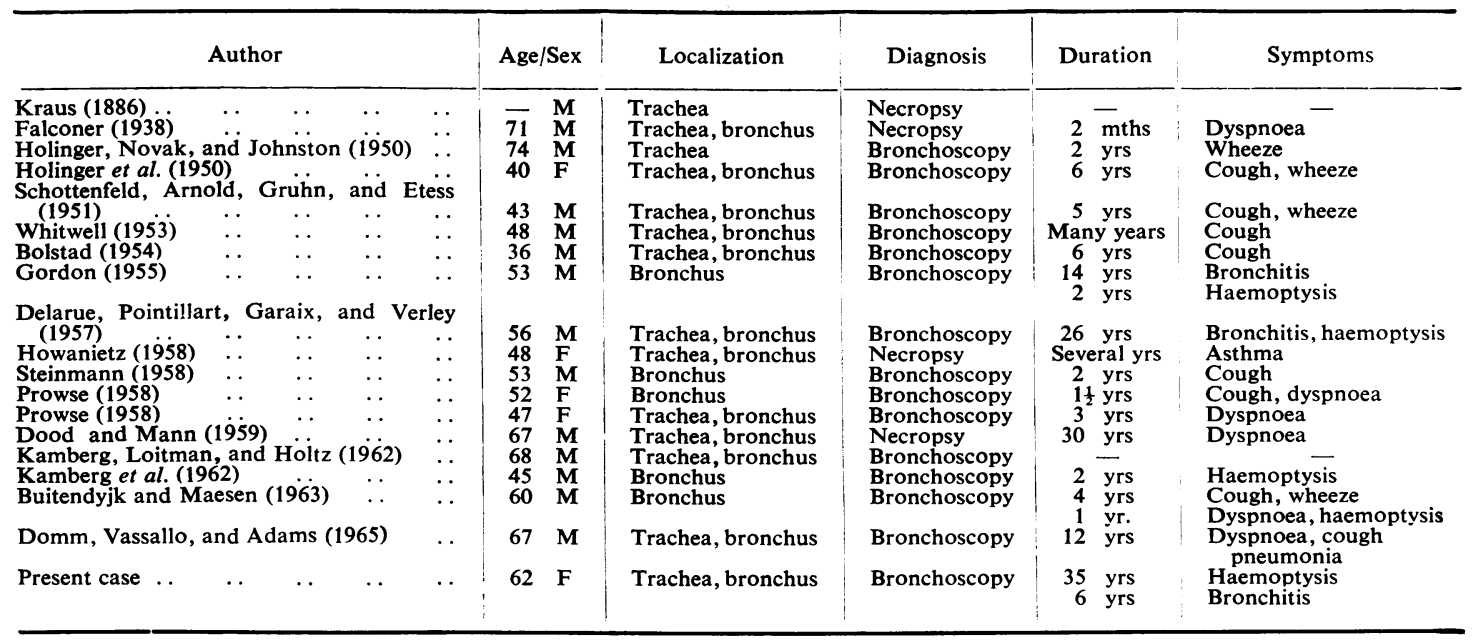


It is possible that more cases would be found if more bronchoscopies and bronchographies were performed in chronic bronchial conditions.

We are indebted to Professor J. C. Pimentel for help with the interpretation of the pathological findings.

Dr. G. Virella kindly performed the electrophoretic and immunoelectrophoretic studies.

\section{REFERENCES}

Bolstad, D. S. (1954). Primary amyloidosis in the lower respiratory tract. Ann. Otol. (St. Louis), 63, 200.

Buitendyjk, H. J., and Maesen, F. (1963). L'amyloïdose primitive de l'arbre bronchique. Presse méd., 71, 1513.

Burow, A. (1875). Amyloide Degeneration von Larynxtumoren, Canüle sieben Jahre lang getragen. Arch. klin. Chir., 18, 242.

Da Silva Horta, J., Filipe, I., and Duarte, S. (1964). Portuguese polyneuritic familial type of amyloidosis. Path. et Microbiol. (Basel), 27, 809.

Delarue, J., Pointillart, J., Garaix, J. P., and Verley, Mme. (1957). Tumeurs amyloïdes localisées de la muqueuse trachéo-bronchique. J. franc. Méd. Chir. thor., 11, 416.

Domm, B. M., Vassallo, C. L., and Adams, C. L. (1965). Amyloid deposition localized to the lower respiratory tract. Amer. J. Med., 38, 151.
Dood, A. R., and Mann, J. D. (1959). Primary diffuse amyloidosis of the respiratory tract. Arch. Path., 67, 39.

Falconer, B. (1938). Ein Fall von Amyloidtumor der Trachea und der grossen Bronchien mit dyspnoischen Erscheinungen. Acta oto-laryng. (Stockh.), 26, 353.

Gordon, W. (1955). Amyloid deposits in the bronchi. Brit. med.J., 1, 825.

Holinger, P. H., Novak, F. G., and Johnston, K. C. (1950). Tumors of the trachea. Laryngoscope (St. Louis), 60, 1086.

Howanietz, L. F. (1958). Uber lokales, tumorartiges Amyloid der unteren Luftwege. Zbl. allg. Path. path. Anat., 97, 527.

Kamberg, S., Loitman, B. S., and Holtz, S. (1962). Amyloidosis of the tracheobronchial tree. New Engl. J. Med., 266, 587.

Kramer, R., and Som, M. L. (1935). Local tumor-like deposits of amyloid in the larynx: report of a case with a review of the literature. Arch. Otolaryng., 21, 324 .

Kraus, F. (1886). Neue Beobachtungen von herdweisem Amyloid. Z. Heilk., 7, 245.

Prowse, C. B. (1958). Amyloidosis of the lower respiratory tract. Thorax, 13, 308.

- and Elliott, R. I. K. (1963). Diffuse tracheo-bronchial amyloidosis: a rare variant of a protean disease. Ibid., 18, 326.

Schottenfeld, A., Arnold, L. M., Gruhn, J. G., and Etess, A. D. (1951). Localized amyloid deposition in the lower respiratory tract. Amer. J. Med., 11, 770.

Steinmann, E. P. (1958). Amyloid der Bronchien. Prac. oto-rhinolaryng. (Basel), 20, 190.

Whitwell, F. (1953). Localized amyloid infiltrations of the lower respiratory tract. Thorax, 8,309 . 